\title{
Identification of an endo-1,4-beta-xylanase of Ustilago maydis
}

\author{
Elena Geiser, Nick Wierckx*, Martin Zimmermann and Lars M Blank
}

\begin{abstract}
Background: The utilization of raw biomass components such as cellulose or hemicellulose for the production of valuable chemicals has attracted considerable research interest in recent years. One promising approach is the application of microorganisms that naturally convert biomass constituents into value added chemicals. One of these organisms - Ustilago maydis - can grow on xylan, the second most abundant polysaccharide in nature, while at the same time it produces chemicals of biotechnological interest.

Results: In this study, we present the identification of an endo-1,4-beta xylanase responsible for xylan degradation. Xylanase activity of $U$. maydis cells was indirectly detected by the quantification of released reducing sugars and could be confirmed by visualizing oligosaccharides as degradation products of xylan by thin layer chromatography. A putative endo-1,4-beta-xylanase, encoded by um06350.1, was identified in the supernatant of xylan-grown cells. To confirm the activity, we displayed the putative xylanase on the surface of the xylanase negative Saccharomyces cerevisiae EBY100. The presented enzyme converted xylan to xylotriose, similar to the source organism U. maydis.

Conclusions: The xylan degradation ability together with its unicellular and yeast-like growth makes $U$. maydis MB215 a promising candidate for the production of valuable chemicals such as itaconic acid or glycolipids from lignocellulosic biomass. Therefore, the characterization of the endo-1,4-beta-xylanase, encoded by um06350.1, is a further step towards the biotechnological application of U. maydis and its enzymes.
\end{abstract}

Keywords: Ustilago maydis, Endo-1,4-beta-xylanase, Xylan, Cell surface display

\section{Background}

In recent years, the efficient use of plant biomass, especially non-food lignocellulosic biomass as renewable resource for biotechnological applications has become increasingly important [1]. This lignocellulosic biomass is composed of cellulose, hemicellulose and lignin [2,3]. Xylan is a major component of hemicellulose, which is the second most abundant plant material in nature and constitutes up to $35 \%$ of the total dry weight of higher plants [4].

The chemical structure of xylan is complex. It consists of a homopolymeric backbone chain of $\beta-1,4-$ linked D-xylose units and short side chains including different amounts of $\alpha$-L-arabinofuranosyl-, O-acetyl-,

\footnotetext{
* Correspondence: nick.wierckx@rwth-aachen.de

iAMB - Institute of Applied Microbiology, ABBt - Aachen Biology and

Biotechnology, RWTH Aachen University, Worringerweg 1, Aachen D-52074, Germany
}

p-coumaroyl-, feruloyl-, D-glucuronopyranosyl- or 4O-methyl-D-glucuronopyranosyl residues depending on the type of plant $[2,3,5]$. Due to this complexity, several enzyme classes are involved in the breakdown of xylan. Hemicellulases, such as $\beta$-D-galactanases, $\beta$ $D$-mannanases or $\beta$-D-xylanases, hydrolyze the 1,4beta- $\mathrm{D}$-glycosidic linkages anywhere in the xylan chain [2,6,7]. Before extensive degradation of the backbone, other enzymes such as acetylesterases, $\alpha$ glucuronidases, $\alpha$-L-arabinofuranosidases, ferulic acid esterases or $p$-coumaric acid esterases remove side chains and substitutes [2,6-8]. Once xylanases have released small xylooligosaccharides, the $\beta$-xylosidases cleave the oligomeric fragments, predominantly to $x y-$ lose [2,6,7]. Additionally, there are many cellulolytic enzymes, which have xylanolytic activity as a secondary function [9]. Synergistic interactions of all these enzymes are required for the efficient degradation of xylan and the exact combination of these enzymes

\section{Biomed Central}


varies from species to species, often with a high degree of redundancy.

Xylan degrading enzymes are produced by a wide variety of aerobic and anaerobic bacteria and fungi, but also algae, protozoa, gastropods and anthropods [2,10-12]. Many of these are saprotrophs, requiring these enzymes for plant degradation and liberation of xylose, a primary carbon source for cell metabolism. Others are plant pathogens requiring hemicellulose degradation for plant cell infection $[2,10]$. Common well-studied xylan degrading organisms are for instance Trichoderma or Aspergillus species [12-19]. Most of their xylan degrading enzymes are identified, characterized and also expressed in other xylanase negative organisms such as Escherichia coli or Saccharomyces cerevisiae $[2,12,20-22]$. In addition to their natural function, xylanases also have a broad range of industrial biotechnological applications including bio bleaching of wood pulp, treatment of animal feed to increase digestibility, processing of food and hydrolysis of lignocellulosic biomass to sugars, which can subsequently be converted into liquid fuels, solvents and other chemicals $[7,12,23,24]$. Especially for the latter applications, organisms efficiently breaking down lignocellulosic biomass are required.

The utilization of raw biomass components for the production of valuable chemicals has attracted considerable research interest in recent years. Ideally, these cheap biomass compounds are utilized by microorganisms that (naturally) produce such valuable chemicals. Ustilago maydis shows this high biotechnological potential and is known to produce chemicals such as glycolipids, itaconic, malic or succinic acid [25-29]. It is a phytopathogenic fungus and belongs to the group of Basidiomycota. It is a biotrophic parasite that causes smut disease in maize, which is characterized by the formation of tumors, called galls, on aerial plant tissue $[30,31]$. Couturier et al. identified Ustilago maydis as the organism with the best biomass-hydrolysis potential out of 20 sequenced fungi such as Trichoderma reesei, Aspergillus terreus or Rhizopus oryzae [32]. Comparing the genomes and secretomes, $U$. maydis showed the widest range of enzymatic activities including 33 hydrolytic enzymes such as polysaccharide hydrolases, polysaccharide lyases and pectin esterases [33]. Nevertheless, the xylanolytic activity of $U$. maydis is lower than that of A. niger or Fusarium graminearum [32]. These predictions are in line with Müller et al. proposing that the secretome of $U$. maydis contains a complete set of hydrolytic enzymes [33]. In contrast, fungi such as Magnaporthe grisea and F. graminearum have more genes encoding hydrolytic enzymes, 138 and 103 respectively, but the variation is lower [30,32]. However, the biotrophic lifestyle of $U$. maydis is geared towards minimizing damage to the host to prevent the release of cell wall fragments, which might trigger plant defense responses [34]. Further, the conditions under which the hydrolytic enzymes are expressed can be very specific [35].

Most of $U$. maydis' enzymes are not at all or not completely characterized so far. Cano-Canchola et al. have described xylanase, pectate lyase, polygalacturonase and cellulase activities in $U$. maydis, but these activities were not linked to specific genes or enzymes [35]. In this study, we confirm the ability of $U$. maydis MB215 to degrade xylan and identify an endo-1,4-beta-xylanase, encoded by um06350, as one of the major components of xylan degradation.

\section{Methods}

\section{Strains, media and growth conditions}

Ustilago maydis strain MB215 (DSM 17144) was used in this work. The fungus was cultivated on YEPS medium consisting of $10 \mathrm{~g} \mathrm{l}^{-1}$ yeast extract, $20 \mathrm{~g} \mathrm{l}^{-1} \mathrm{D}$-sucrose, and $20 \mathrm{~g} \mathrm{l}^{-1}$ peptone for at least $48 \mathrm{~h}$ at $28^{\circ} \mathrm{C}$ and 150 $\mathrm{rpm}$. Physiological experiments were performed in $50 \mathrm{ml}$ minimal medium ( $\mathrm{pH}$ 5.2) containing $1.6 \mathrm{~g} \mathrm{l}^{-1} \mathrm{NH}_{4} \mathrm{Cl}$, $0.5 \mathrm{~g} \mathrm{l}^{-1} \mathrm{KH}_{2} \mathrm{PO}_{4}, 0.2 \mathrm{~g} \mathrm{l}^{-1} \mathrm{MgSO}_{4}, 0.17 \mathrm{~g} \mathrm{l}^{-1} \mathrm{FeSO}_{4}$ and $20 \mathrm{~g} \mathrm{l}^{-1}$ of varying carbon sources such as xylan from birch wood (Carl Roth $\mathrm{GmbH}$, Germany), glucose and xylose in $500 \mathrm{ml}$ Erlenmeyer flasks at $28^{\circ} \mathrm{C}$ and $150 \mathrm{rpm}$. Through the process of autoclaving, xylan was almost completely dissolved. All cultures were inoculated to a starting $\mathrm{OD}_{600}$ of 0.5 .

Escherichia coli DH5 $\alpha$ (DSM 6897) was used as a host for DNA manipulation and was grown in lysogeny broth (LB) medium at $37^{\circ} \mathrm{C}$ and $250 \mathrm{rpm}$. For plasmid selection, recombinant $E$. coli $\mathrm{DH} 5 \alpha$ strains were grown in the presence of $50 \mathrm{mg} \mathrm{l}^{-1}$ ampicillin.

The surface display strain S. cerevisiae EBY100 was cultivated according to the manufacturer's manual [pYD1 Yeast Display Vector Kit Manual, Invitrogen, Germany].

\section{Analytical methods}

Cell densities were measured by determining the absorption at $600 \mathrm{~nm}$ with a Unico spectrophotometer 1201. For dry weight determination $5 \mathrm{ml}$ culture broth was filtered using Macherey-Nagel Paper MN218B (Macherey-Nagel, Germany) and weighed after drying at $110^{\circ} \mathrm{C}$ for $24 \mathrm{~h}$.

The ammonium concentration in the culture supernatant was measured by a colorimetric method according to Willis using salicylate and nitroprusside [36].

The concentration of reducing sugars was determined by a modified version of the Nelson Somogyi assay [37]. A fresh working solution $\left(12 \mathrm{~g} \mathrm{l}^{-1} \mathrm{~K}-\mathrm{Na}\right.$-Tartrate, $24 \mathrm{~g} \mathrm{l}^{-1}$ $\mathrm{Na}_{2} \mathrm{CO}_{3}, 16 \mathrm{~g} \mathrm{l}^{-1} \mathrm{NaHCO}_{3}, 180 \mathrm{~g} \mathrm{l}^{-1} \mathrm{Na}_{2} \mathrm{SO}_{4}$ and $4 \mathrm{~g} \mathrm{l}^{-1}$ $\mathrm{CuSO}_{4} 4 \cdot \mathrm{H}_{2} \mathrm{O}$ ) was prepared. $0.5 \mathrm{ml}$ of this solution were added to $0.5 \mathrm{ml}$ sample containing not more than 
$0.1 \mathrm{~g} \mathrm{l}^{-1}$ reducing sugars and the mixture was boiled for $15 \mathrm{~min}$. After cooling on ice, $0.5 \mathrm{ml}$ of staining solution $\left(48 \mathrm{~g} \mathrm{l}^{-1}\left(\mathrm{NH}_{4}\right)_{6} \mathrm{Mo}_{7} \mathrm{O}_{24} 4 \cdot \mathrm{H}_{2} \mathrm{O}, 4.2 \%(\mathrm{v} / \mathrm{v}) \mathrm{H}_{2} \mathrm{SO}_{4}\right.$ and 6 $\mathrm{g} \mathrm{l}^{-1} \mathrm{Na}_{2} \mathrm{HAsO}_{4} \quad 7 \cdot \mathrm{H}_{2} \mathrm{O}$ ) were added and mixed for 0.5 min. Reducing sugar concentrations were determined from absorbance at $520 \mathrm{~nm}$. A standard curve was prepared using appropriate amounts of xylose $\left(0-0.1 \mathrm{~g} \mathrm{l}^{-1}\right)$.

Xylan degradation products were analyzed by thinlayer chromatography (TLC). $5 \mu$ l of the culture broth and standards were spotted on a silica gel SIL G-25 TLC plate $(20 \mathrm{~cm} \times 20 \mathrm{~cm} \times 0.25 \mathrm{~mm}$, Macherey-Nagel, Germany). 50\% (v/v) formate, 33\% (v/v) butanol and $17 \%(\mathrm{v} / \mathrm{v}) \mathrm{H}_{2} \mathrm{O}$ were used as running buffer. For staining, the plate was dipped in a mix of $90 \%(\mathrm{v} / \mathrm{v})$ ethanol and $10 \%(\mathrm{v} / \mathrm{v})$ of an aqueous $200 \mathrm{~g} \mathrm{l}^{-1} \mathrm{H}_{2} \mathrm{SO}_{4}$ solution followed by $20 \mathrm{~min}$ of heating at $130^{\circ} \mathrm{C} .20 \mathrm{~g} \mathrm{l}^{-1}$ xylan, $5 \mathrm{~g} \mathrm{l}^{-1}$ xylose, $5 \mathrm{~g} \mathrm{l}^{-1}$ xylobiose and $5 \mathrm{~g} \mathrm{l}^{-1}$ xylotriose solutions served as standards.

For identification of proteins present in the supernatant of an $U$. maydis culture $50 \mathrm{ml}$ culture broth was centrifuged at $7000 \mathrm{rpm}$ for $10 \mathrm{~min}$. The supernatant was lyophilized and resuspended in $5 \mathrm{ml} 10 \mathrm{mM}$ Tris$\mathrm{HCl} \mathrm{pH} \mathrm{7.5.} \mathrm{For} \mathrm{protein} \mathrm{separation} \mathrm{a} \mathrm{sodium} \mathrm{dodecyl}$ sulfate polyacrylamide gel electrophoresis (SDS-PAGE) on NuPAGE ${ }^{\oplus}$ Novex $^{\oplus} 12 \%$ Bis-Tris Mini gels in NuPAGE ${ }^{\oplus}$ MOPS SDS Running Buffer was performed according to the manufacturers manual (Invitrogen, Germany). The gel was stained with a $0.23 \%(w / v)$ Coomassie Blue R-250 solution for $15 \mathrm{~min}$. Favored slots were cut out and de-stained in $5 \%(\mathrm{v} / \mathrm{v})$ methanol and $7 \%(\mathrm{v} / \mathrm{v})$ acetic acid. The de-stained gel slices were washed and equilibrated in $350 \mu \mathrm{l} 30 \%(\mathrm{v} / \mathrm{v})$ acetonitrile in $0.1 \mathrm{M}$ ammonium hydrogen carbonate for $10 \mathrm{~min}$. Afterwards, the supernatant was discarded and the residual acetonitrile was removed in a Speed Vac vacuum centrifuge. Further steps, such as trypsin-digestion, liquid chromatography peptide fractionation, matrix preparation, MALDI-TOF/TOF mass spectrometry and database search, required for the identification of the expressed proteins, were kindly performed by Benjamin Müller (University Bielefeld, Germany) and are described in Additional file 1.

\section{Cloning procedures}

Standard cloning-related techniques were performed according to Sambrook et al. [38]. As a reference sequence the genomic sequence of $U$. maydis 521 (accession number: NW_101210) was used.

A gene replacement construct for disruption of umxyn11A (um06350) was constructed by a reverse genetic approach described by Brachmann et al. [39]. An upstream flank was amplified from $U$. maydis MB215 genomic DNA with the primers LF-fwd 5'-GTCAATA TTCTTGTTAACGATCTCAGCCTCATG-3' and LF-rev
5'-ACTGGCCATCTAGGCCCTTGAATGTTCGAAGAA GAGATCGATGGC-3' by PCR.

Similarly, the downstream flank was amplified with the primers RF-fwd 5'-AGCGGCCTGAGTGGCCACGTTG AGAGGCCGGATCGGACAGG-3' and RF-rev 5'- GAC AATATTGACCATCAGATTCTTTCAGTCCATGCC-3'. The hygromycin resistance cassette originated from the vector pMF1h [39]. The flanks and the hygromycin resistance cassette were digested with SfiI (indicated by italic sequences) and ligated to obtain the complete replacement construct. This construct was transformed into U. maydis MB215 protoplasts. Successful homologous integration was tested by colony PCR and single copy integration was verified via Southern blot analysis.

The strain S. cerevisiae EBY100/pYD1+umxyn11A expressing the putative endo-1,4-beta-xylanase (UmXyn11A) of $U$. maydis MB215 on its cell surface was constructed as follows. The umxyn11A gene (um06350) was amplified with primers 5'- AAAAAAGAATTCATGAAGTTTGCC ACTGTCCTTGC-3' and 5'-AAAAAAGAGCGGCCGCC AACCAGAGACGGACATCGAGGC-3' from $U$. maydis MB215 genomic DNA by PCR. The umxyn11A gene and the cell surface display vector pYD1 (Invitrogen) were digested with EcoRI and NotI (indicated by italic sequences). Afterwards the fragment was ligated into the vector and transformed into $E$. coli $\mathrm{DH} 5 \alpha$ to obtain the strain E. coli DH5 $/ \mathrm{pYD} 1+u m x y n 11 A$. The umxyn $11 A$ gene was sequenced to confirm the correct sequence and orientation. The transformation of the vector pYD1+ umxyn11A in S. cerevisiae EBY100 and expression of the UmXyn11A on the cell surface was performed according to the manufacturer's manual.

\section{Results and discussion}

\section{Xylan degradation by Ustilago maydis MB215}

In order to characterize the xylan degrading abilities of $U$. maydis, strain MB215 was cultivated in minimal medium with xylan as sole carbon source (Figure 1). Growth stopped after $28 \mathrm{~h}$ at a maximal $\mathrm{OD}_{600}$ of $8.18 \pm$ 0.07 , corresponding to $3.82 \pm 0.09 \mathrm{~g} \mathrm{l}^{-1}$ cell dry weight $(\mathrm{CDW})$. The maximal growth rate was $0.10 \pm 0.00 \mathrm{~h}^{-1}$. Given this low biomass concentration in comparison to the initial substrate of $15 \mathrm{~g} \mathrm{l}^{-1}$, approximately half of the C-source was likely still present. During the same time the ammonium concentration in the supernatant decreased from $0.58 \pm 0.01 \mathrm{~g} \mathrm{l}^{-1}$ to $0.27 \pm 0.01 \mathrm{~g} \mathrm{l}^{-1}$.

The cessation of growth after $28 \mathrm{~h}$, despite the availability of an $\mathrm{N}$ and $\mathrm{C}$ source, is probably caused by the $\mathrm{pH}$ drop from $5.63 \pm 0.01$ to $3.37 \pm 0.01$ (Figure 1). The ammonium consumption of $17 \mathrm{mM}$ accompanied by an equal release of protons lowers the $\mathrm{pH}$ by 1.77 , which is in line with Figure 1. U. maydis is known to secrete small organic acids such as itaconic, 2-hydroxyparaconic, itatartaric, and malic acid [29], but HPLC analysis could 


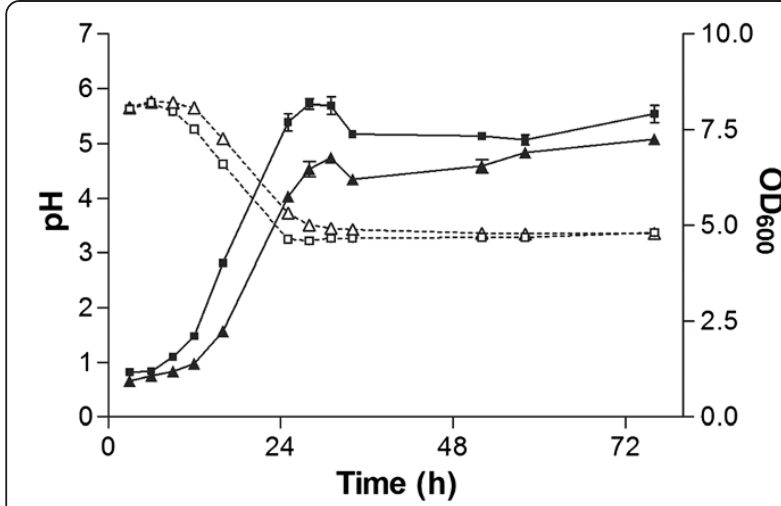

Figure $1 O D_{600}$ (solid lines, filled symbols) and $\mathrm{pH}$ (dashed lines, open symbols) of a U. maydis MB215 $(\square, \square)$ and U. maydis MB215 $\triangle 06350(\Delta, \Delta)$ culture in minimal medium containing xylan.

Error bars indicated deviation from the mean $(n=2)$.

not detect any of these in the culture supernatant (data not shown).

$U$. maydis species are known to grow at low $\mathrm{pH}$ levels down to 2 [40], which was also confirmed by control experiments with xylose as sole carbon source (Figure 2). The cultures on xylose showed a similar growth behavior, $\mathrm{pH}$ trend and $\mathrm{N}$ consumption with a final cell dry weight of $3.66 \pm 0.11 \mathrm{~g} \mathrm{l}^{-1}$ compared to cultures grown on xylan (Figure 2). Apparently the xylan degrading enzymes had low activity around $\mathrm{pH} 3$ which is in line with other fungal xylanases showing enzymatic activity in a pH range of 3-8 [7].

Xylan degradation was indirectly determined via quantification of released reducing sugars using the Nelson Somogyi method (Figure 3). The maximal reducing sugar concentration was $3.07 \pm 0.01 \mathrm{~g} \mathrm{l}^{-1}$ after $16 \mathrm{~h}$ of cultivation. This concentration decreased rapidly after

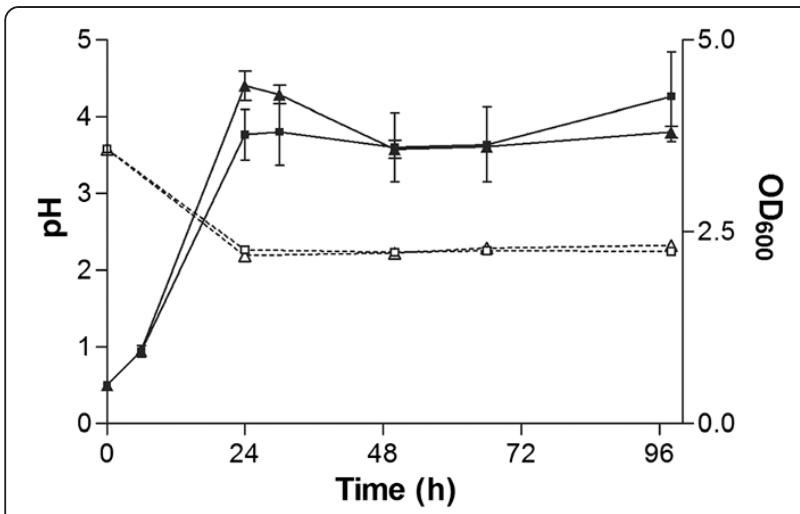

Figure $2 O D_{600}$ (solid lines, filled symbols) and $p H$ (dashed lines, open symbols) of $a \mathrm{U}$. maydis MB215 $(\square, \square)$ and $\mathrm{U}$. maydis MB215 $\triangle 06350(\Delta, \Delta)$ culture in minimal medium containing xylose. Error bars indicated deviation from the mean $(n=2)$.

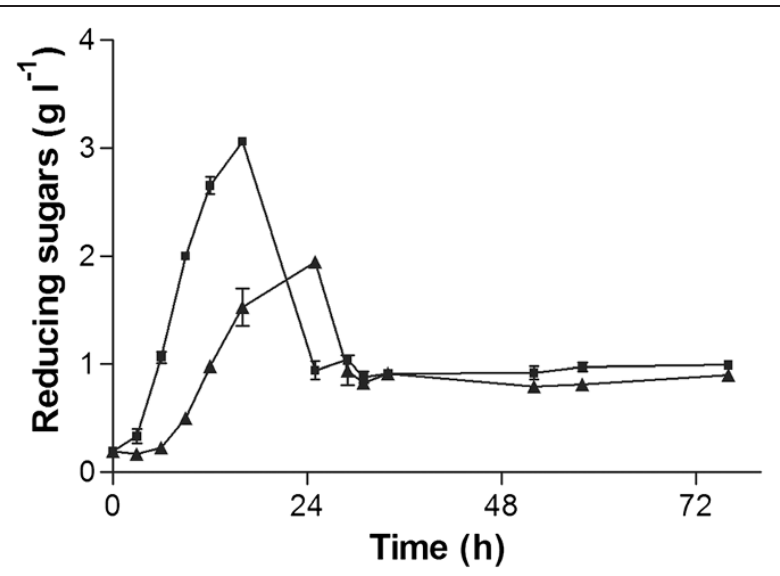

Figure 3 Concentration of reducing sugars released by $\mathrm{U}$. maydis MB215 (⿴) and U. maydis MB215 $\triangle 06350$ ( $\mathbf{\Delta}$ ) during cultivation in minimal medium containing xylan. Error bars indicated deviation from the mean $(n=2)$.

the $\mathrm{pH}$ drop at $28 \mathrm{~h}$ of cultivation to a stable value of about $0.96 \pm 0.03 \mathrm{~g} \mathrm{l}^{-1}$.

Additionally, xylan degradation was confirmed by visualizing the hydrolysis products via TLC (Figure 4). In the first phase of cultivation different xylo-oligosaccharides accumulated, but after $25 \mathrm{~h}$ only xylotriose was left in the supernatant, indicating the presence of a xylanase with endo-acting nature [2,16]. Xylobiose and xylose itself were not found (additionally confirmed by HPLC analysis, data not shown), likely because they were consumed and utilized for biomass formation. These results are in line with the theory of Collins et al. proposing that xylanases are excreted in small amounts into the medium liberating xylo-oligomers, which may be transported into the cell for continuing degradation by beta-xylosidases or intracellular xylanases and induction of further xylanase expression [2]. Intracellular xylanases are known for example in Bacillus stearothermophilus or Prevotella bryantii as well as intracellular xylosidases in Klebsiella oxytoca [23,41,42]. This fast xylo-oligomer uptake and intracellular degradation can also be advantageous in densely populated ecosystems concerning the interspecies competition for nutrients $[41,43]$.

Interestingly, after $25 \mathrm{~h}$ a gel-like precipitate in high concentrations (up to $4.8 \pm 0.64 \mathrm{~g} \mathrm{l}^{-1}$ ) was observed (Figure 5). This precipitation coincided with the drop in reducing sugars (Figure 3) and the disappearance of the high molecular weight (HMW) spot at the bottom of the TLC (Figure 4). Control experiments under the same conditions with xylose or glucose instead of xylan did not show this precipitation, nor did it occur in xylan containing medium without inoculation, even when the $\mathrm{pH}$ was reduced to 3.2 with DL-malic acid. Thus, the precipitate is likely the result of a modification of the HMW xylan by $\mathcal{U}$. maydis MB215. The precipitate was 


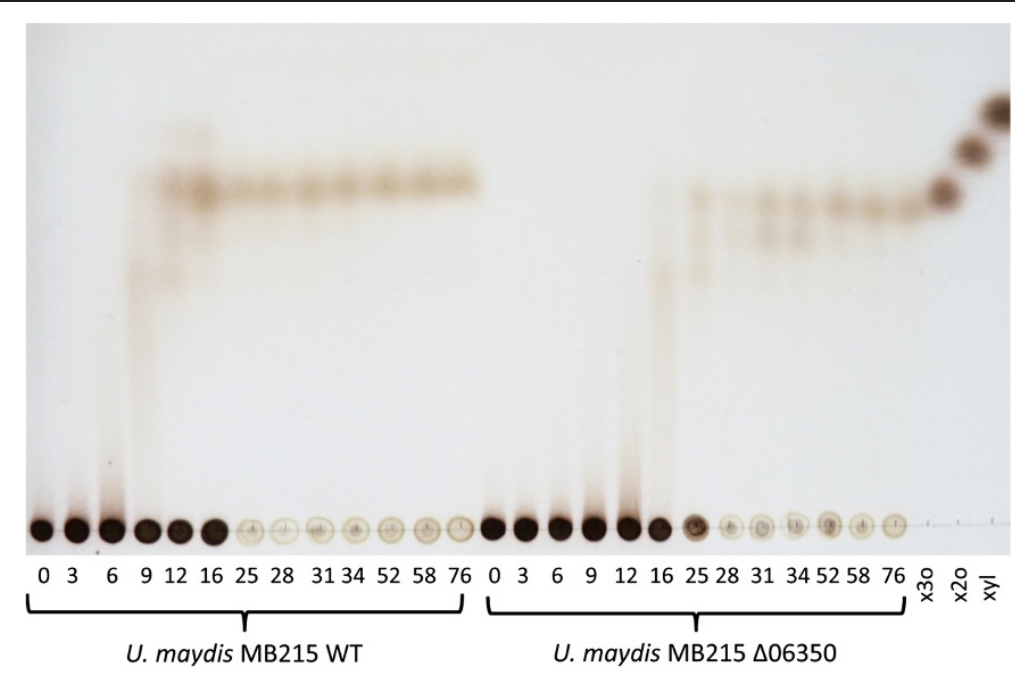

Figure 4 Analysis of the xylan hydrolysis products in the supernatant of a U. maydis MB215 and a U. maydis MB215 $\triangle 06350$ culture grown on xylan at different time points (in h) by TLC, x3o: $5 \mathrm{~g} \mathrm{I}^{-1}$ xylotriose; $x 20: 5 \mathrm{~g} \mathrm{I}^{-1}$ xylobiose; $x y l$ : $5 \mathrm{~g} \mathrm{I}^{-1}$ xylose solution.

not soluble in water, methanol or ethanol, but it dissolved completely in a $3 \mathrm{M} \mathrm{NaOH}$ solution indicating that it contains a carboxylic acid moiety. Possibly, acidic side chains such as glucopyranosyluronic acid formed during the xylan degradation, causing the precipitation in the low $\mathrm{pH}$ environment [44].

\section{Identification of $U$. maydis' xylanases}

To find the enzymes responsible for xylan degradation, we searched for probable xylan degrading enzymes in

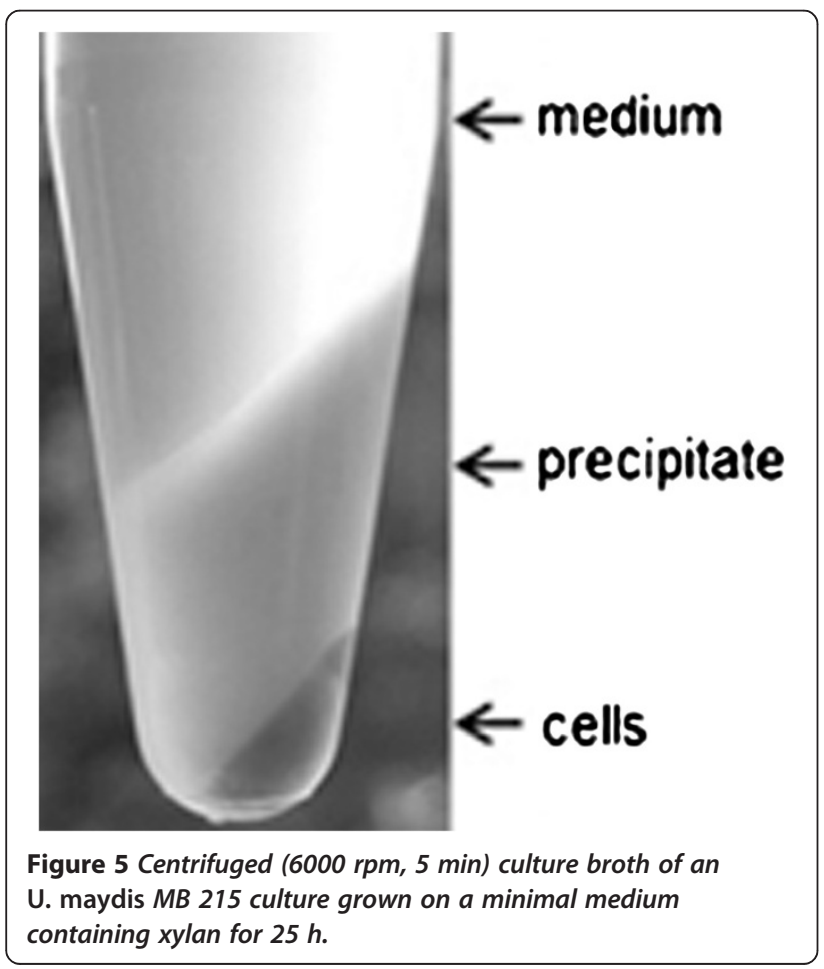

the genome of the reference strain $U$. maydis 521 . According to Müller et al. at least 12 open reading frames (ORFs) are present in the secretome of $U$. maydis, whose products could be responsible for the xylan degradation [33]. Four of these enzymes are putative endo-1,4beta-xylanases (um06350.1, um03411.1, um04422.1 and um04897.1), three alpha-L-arabinofuranosidases (um01829, um03416, um01427), two beta-galactosidases (um02204, um02356) and acetylxylan-esterases (um11763, um04687) and one arabinoxylan arabinfuranohydrolase (um04309) [33].

MALDI-TOF analysis of a $U$. maydis MB215 culture grown on xylan confirmed that the putative endo-1,4beta-xylanase encoded by um06350.1 was present in the supernatant, together with other biomass degrading enzymes such as arabinoxylan arabinfuranohydrolases, glucanases, glycosyl hydrolases and galactosidases (Table 1). Altogether 14 proteins were found in the supernatant of which 9 have putative biomass degrading activity.

The other probable xylan degrading enzymes were not present in the supernatant, although they were predicted as secreted enzymes containing a signal peptide cleavage site in their amino acid sequences [33,45]. Different regulatory induction mechanisms could be a reason for the absence of these enzymes in the supernatant, since certain external conditions (e.g., substrate variety and concentration, host type and host presence) are required for their expression $[35,46]$.

All proteins identified in Table 1 were also found by Couturier et al. except for one (um06247.1). However, altogether fewer proteins were found in our study, which can be explained by the fact that Couturier et al. used complex media with maize bran as carbon source. This 
Table 1 Putative proteins in the supernatant of a U. maydis MB215 culture grown on xylan detected by MALDI-TOF analysis

\begin{tabular}{|c|c|c|c|c|c|c|c|c|}
\hline $\begin{array}{c}\text { Putative enzyme } \\
\text { activity }\end{array}$ & Gene(s) & Score $^{A}$ & $\begin{array}{c}\mathrm{M}_{\mathrm{w}} \\
{[\mathrm{kDa}]}\end{array}$ & $\mathrm{pl}$ & $\begin{array}{c}\text { Sequence coverage } \\
{[\%]^{\mathrm{A}}}\end{array}$ & $\begin{array}{l}\text { Number of } \\
\text { peptides }{ }^{A}\end{array}$ & $\begin{array}{l}\text { CAZy } \\
\text { family }\end{array}$ & Remark \\
\hline endo-1,4-beta-xylanase & um06350.1 & $87 / 111$ & 23.8 & 9.41 & $24.0 / 18.1$ & $4 / 3$ & $\mathrm{GH} 11$ & xylan degradation \\
\hline $\begin{array}{l}\text { arabinoxylan } \\
\text { arabinofurano-hydrolase }\end{array}$ & um04309.1 & $149 / 142$ & 36.3 & 9.00 & 21.1/13.6 & $5 / 3$ & GH62 & xylan degradation \\
\hline glycosidase & um02727.1 & $179 / 180$ & 25.1 & 9.27 & $26.7 / 26.7$ & $3 / 3$ & $\mathrm{GH} 25$ & D-glucan degradation \\
\hline $\begin{array}{l}\text { endo-1,3(4)- } \\
\text { beta-glucanase }\end{array}$ & um02134.1 & $331 / 58$ & 41.5 & 5.84 & $17.3 / 2.3$ & $4 / 1$ & GH16 & D-glucan degradation \\
\hline glycosyl hydrolase & um06247.1 & $65 / 85$ & 54.0 & 5.98 & $4.47 / 4.4$ & $2 / 2$ & & $\begin{array}{l}\text { (hemi-) /cellulose } \\
\text { degradation }\end{array}$ \\
\hline chitin deacetylase & um02689.1 & $-/ 100$ & 52.4 & 6.63 & $-/ 6.0$ & $-/ 2$ & CE4 & $\begin{array}{l}\text { polysaccharide } \\
\text { degradation }\end{array}$ \\
\hline lipase B & um01422.1 & $118 / 130$ & 35.1 & 8.81 & $8.3 / 8.3$ & $2 / 2$ & & lipid degradation \\
\hline aspartic protease & um00064.1 & $316 / 338$ & 41.5 & 5.80 & 17.1/17.1 & $4 / 4$ & & peptide degradation \\
\hline alpha-galactosidase & um04503.1 & $153 / 138$ & 60.5 & 6.58 & $8.6 / 4.7$ & $3 / 2$ & $\mathrm{GH} 27$ & $\begin{array}{l}\text { galactomannan } \\
\text { degradation }\end{array}$ \\
\hline spherulin 4 & um06157.1 & $237 / 150$ & 35.5 & 9.67 & $24.7 / 14.5$ & $4 / 3$ & & spherulin-like protein \\
\hline choline dehydrogenase & um03246.1 & $222 / 176$ & 67.9 & 6.30 & $8.0 / 6.5$ & $5 / 3$ & & $\begin{array}{l}\text { glycine, serine and } \\
\text { threonine metabolism }\end{array}$ \\
\hline uncharacterized protein & um05604.1 & $88 / 101$ & 27.0 & 4.65 & $6.0 / 6.0$ & $3 / 3$ & & unknown \\
\hline uncharacterized protein & um01894.1 & $49 / 48$ & 30.4 & 5.53 & $6.5 / 6.5$ & $2 / 2$ & & unknown \\
\hline uncharacterized protein & um00961.1 & $367 / 371$ & 31.6 & 6.19 & $24.8 / 20.7$ & $4 / 3$ & & unknown \\
\hline
\end{tabular}

A: numbers are given for both analyses of a biological replicate.

${ }^{B}$ : CAZy families are signed according to Cantarel et al. [47].

indicates that the induction of different components of the biomass-degrading machinery of $U$. maydis is individually regulated.

In order to characterize the xylan degrading ability of $U$. maydis we concentrated on the identified putative endo-1,4-beta-xylanase. UM06350 is defined as UmXyn11A since the enzyme belongs to the GH11 family [47]. First annotation was done by Couturier et al. [32]. According to the MUMDB Ustilago database the umxyn11A gene (um06350.1) has a size of $666 \mathrm{nt}$ and does not contain predicted introns [48].

\section{Effect of the deletion of um06350 on Ustilago maydis MB215}

To confirm the xylanase activity of UmXyn11A, we deleted the corresponding ORF and checked the xylan degradation ability of this deletion mutant. Notably, the deletion of the umxyn11A gene reduced the growth rate of the mutant $U$. maydis MB215 $\Delta 06350$ on minimal medium with xylan to $0.09 \pm 0.00 \mathrm{~h}^{-1}$ compared to $0.10 \pm 0.00 \mathrm{~h}^{-1}$ of the wildtype (Figure 1). The deletion mutant reached a final $\mathrm{OD}_{600}$ of $6.78 \pm 0.00$, compared to $8.18 \pm 0.07$ in the wildtype culture. However, the final CDW of $4.50 \pm 0.04 \mathrm{~g} \mathrm{l}^{-1}$ is similar to the wildtype. The drop of the $\mathrm{pH}$ value from initially $5.66 \pm 0.00$ to $3.36 \pm 0.01$ was approximately $3 \mathrm{~h}$ delayed in comparison to $U$. maydis MB215 (Figure 1). Also the maximal concentration of reducing sugars was lower $\left(1.95 \pm 0.03 \mathrm{~g} \mathrm{l}^{-1}\right)$, and occurred $9 \mathrm{~h}$ later than in the wildtype culture (Figure 3). In the end of cultivation the reducing sugar concentration decreased to $0.87 \pm$ $0.03 \mathrm{~g} \mathrm{l}^{-1}$ similar to the wildtype. Analyzing hydrolytic products via TLC also showed that the release of smaller xylo-oligosaccharides by the deletion mutant was slower than in the wildtype. After $52 \mathrm{~h}$, xylotriose was the only xylo-oligosaccharide detectable in the supernatant. These results indicate that the deletion of the selected umxyn11A locus had a negative influence on the rate of xylan degradation of $U$. maydis MB215 $\Delta 06350$, although the overall growth on xylan was not affected. Redundant xylan-degrading activity of the other mentioned xylanases was apparently still sufficient to support growth. The deletion mutant growing on xylose as sole carbon source showed the same growth rate and $\mathrm{N}$-consumption as the wildtype indicating no polar effect of the umxyn $11 \mathrm{~A}$ deletion (Figure 2). This confirmed the assumption, that the deleted ORF is involved in the xylan degradation and not in growth processes or xylose uptake mechanism.

\section{Heterologous expression of UmXyn11A on the cell surface of Saccharomyces cerevisiae}

For further confirmation of the xylanase activity we displayed the UmXyn11A on the cell surface of a 


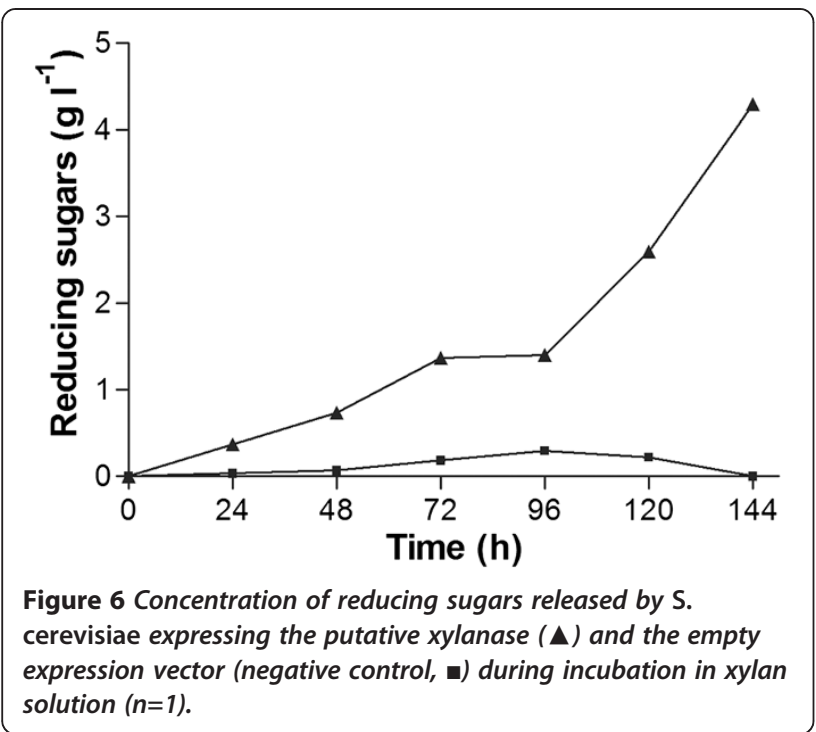

xylanase-negative strain, $S$. cerevisiae EBY100. This strain can neither utilize xylan nor xylose nor xylooligosaccharides [49]. With the help of the cell surface display vector pYD1, we constructed the strain $S$. cerevisiae EBY100/pYD1+umxyn11A, expressing the UmXyn11A attached to the cell surface via disulphide bonds after induction with galactose. The correct expression of UmXyn11A was confirmed by Western analysis (data not shown). The strain S. cerevisiae EBY100/ pYD1 was used as a negative control.

The enzyme activity of the displayed UmXyn11A was determined by measuring the increase of released

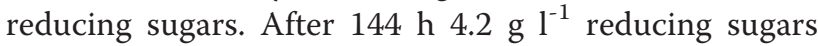
were formed upon incubation of S. cerevisiae EBY100/ pYD1+umxyn11A with $15 \mathrm{~g} \mathrm{l}^{-1}$ xylan solution by the displayed UmXyn11A, compared to $0.0 \mathrm{~g} \mathrm{l}^{-1}$ reducing sugars in the negative control not expressing any xylan degrading enzymes (Figure 6). Therefore, the strain S. cerevisiae EBY100/pYD1+umxyn11A almost completely degraded xylan to xylotriose, which was additionally confirmed by TLC (data not shown).

\section{Conclusions}

This study showed that $U$. maydis MB215 is able to degrade xylan. The recombinant expression of UmXyn11A (um06350.1) supports that it is involved in xylan degradation, and the resulting degradation products are in accordance with the activity of an endo-1,4-beta-xylanase [2,16]. As already suggested by the genome sequence, the deletion mutant shows that $U$. maydis MB215 possesses other genes coding for xylan degrading enzymes. For comparison with other xylanases of well-characterized strains, such as $T$. reese $i$, further characterization has to be performed concerning the determination of the specific enzyme activity, substrate specificity or $\mathrm{pH}$ and temperature optima.

This xylan degradation ability together with its unicellular and yeast-like growth makes $U$. maydis MB215 a promising candidate for the production of valuable chemicals such as itaconic acid or glycolipids from lignocellulosic biomass. Thus, the characterization of this enzyme is a further step towards the biotechnological application of $U$. maydis and its enzymes.

\section{Additional file}

Additional file 1: Methods for trypsin-digestion, liquid chromatography peptide fractionation, matrix preparation, MALDITOF/TOF mass spectrometry and database search.

Competing interests

The authors declare that there are no competing interests.

\section{Authors' contributions}

LMB and MZ conceived and designed the study. EG performed the experimental work. All authors interpreted experimental data. EG and NW wrote the manuscript. All authors read and approved the submission of the manuscript.

\section{Acknowledgements}

This work was performed as a part of the Cluster of Excellence "Tailor-Made Fuels from Biomass", which is funded by the Excellence Initiative of the German federal and state governments to promote science and research at German universities. The strain U. maydis MB215 was kindly provided by Prof. Michael Bölker and U. maydis MB215 $\Delta 06350$ was constructed by Sandra Przybill (Philipps-University of Marburg, Germany). MALDI-TOF analysis was kindly performed by Benjamin Müller (University Bielefeld, Germany).

Received: 9 April 2013 Accepted: 22 July 2013

Published: 26 July 2013

\section{References}

1. Ragauskas AJ, Williams CK, Davison BH, Britovsek G, Cairney J, Eckert CA, Frederick WJ, Hallett JP, Leak DJ, Liotta CL, Mielenz JR, Murphy R, Templer R, Tschaplinski T: The path forward for biofuels and biomaterials. Science 2006, 311(5760):484-489

2. Collins T, Gerday C, Feller G: Xylanases, xylanase families and extremophilic xylanases. FEMS Microbio/ Rev 2005, 29:3-23.

3. Kulkarni N, Shendye A, Rao M: Molecular and biotechnological aspects of xylanases. FEMS Microbiol Rev 1999, 23:411-456.

4. Haltrich D, Nidetzky B, Kulbe KD, Steiner W, Zupancic S: Production of fungal xylanases. Bioresour Technol 1996, 58:137-161.

5. Li K, Azadi P, Collins R, Tolan J, Kim JS, Eriksson KEL: Relationships between activities of xylanases and xylan structures. Enzyme Microb Technol 2000, 27:89-94.

6. Biely P: Microbial xylanolytic systems. Trends Biotechnol 1985, 3:286-290.

7. Subramaniyan S, Prema P: Biotechnology of microbial xylanases: enzymology, molecular biology, and application. Crit Rev Biotechnol 2002, 22:33-64.

8. Puls J, Schmidt O, Granzow C: Glucuronidase in two microbial xylanolytic systems. Enzyme Microb Technol 1986, 9:83-88.

9. Thomson JA: Molecular biology of xylan degradation. FEMS Microbiol Rev 1993, 104:65-82.

10. Prade RA: Xylanases: from biology to biotechnology. Biotechnol Genet Eng Rev 1995, 13:100-131.

11. Sunna A, Antranikian G: Xylanolytic enzymes from fungi and bacteria. Crit Rev Biotechnol 1997, 17(1):39-67.

12. Polizeli MLTM, Rizzatti ACS, Monti R, Terenzi HF, Jorge JA, Amorim DS: Xylanases from fungi: properties and industrial applications. Appl Microbiol Biotechnol 2005, 67:577-591. 
13. Chaudhary K, Tauro P: Synthesis of xylanase by Trichoderma reesei. MIRCEN J App/ Microbiol Biotechnol 1986, 2:399-403.

14. Fujita Y, Katahira S, Ueda M, Tanaka A, Okada H, Morikawa Y, Fukuda H, Kondo A: Construction of whole-cell biocatalyst for xylan degradation through cell-surface xylanase display in Saccharomyces cerevisiae. J Mol Catal B Enzym 2002, 17:189-195.

15. Gawande PV, Kamat MY: Production of Aspergillus xylanase by lignocellulosic waste fermentation and its application. J Appl Microbiol 1999, 87:511-519.

16. He J, Yu B, Zhang K, Ding X, Chen D: Expression of endo-1, 4-beta -xylanase from Trichoderma reesei in Pichia pastoris and functional characterization of the produced enzyme. BMC Biotechnol 2009, 9:56-66.

17. Smith DC, Bhat KM, Wood TM: Xylan-hydrolysing enzymes from thermophilic and mesophilic fungi. World J Microbiol Biotechnol 1991 7:475-484.

18. Törrönen A, Mach RL, Messner R, Gonzalez R, Kalkkinen N, Harkki A, Kubicek CP: The two major xylanases from Trichoderma reesei: characterization of both enzymes and genes. Nat Biotechnol 1992, 10:1461-1465.

19. Uchida H, Kusakabe I, Kawabata Y, Ono T, Murakami K: Production of xylose from xylan with intracellular enzyme system of Aspergillus niger 5-16. J Ferment Bioeng 1992, 74(3):153-158.

20. Dalbøge $\mathrm{H}$ : Expression cloning of fungal enzyme genes; a novel approach for efficient isolation of enzyme genes of industrial relevance. FEMS Microbiol Rev 1997, 21(1):29-42.

21. Grange DC, Pretorius IS, van-Zy| WH: Expression of a Trichoderma reesei beta-xylanase gene (XYN2) in Saccharomyces cerevisiae. Appl Environ Microbiol 1996, 62(3):1036.

22. Horikoshi K: Alkaliphiles - from an industrial point of view. FEMS Microbiol Rev 1996, 18:259-270.

23. Burchhardt $G$, Ingram LO: Conversion of xylan to ethanol by ethanologenic strains of Escherichia coli and Klebsiella oxytoca. Appl Environ Microbiol 1992, 58(4):112-1133.

24. Wong KKY, Tan LUL, Saddler JN: Multiplicity of 3-1,4-xylanase in microorganisms: functions and applications. Microb Rev 1988, 52(3):305-317

25. Spoeckner S, Wray V, Nimtz M, Lang S: Glycolipids of the smut fungus Ustilago maydis from cultivation on renewable resources. Appl Microbiol Biotechnol 1999, 51:33-39.

26. Liu J, Koh CMJ, Ji L: Bioconversion of crude glycerol to glycolipids in Ustilago maydis. Bioresour Technol 2011, 102(4):3927-3933.

27. Feldbrügge M, Kellner R, Schipper K: The biotechnological use and potential of plant pathogenic smut fungi. Appl Microbiol Biotechnol 2013. DOI 10.1007/s00253-013-4777-1.

28. Klement T, Milker S, Jäger G, Grande PM, Büchs J, Domínguez de María P: Biomass pretreatment affects Ustilago maydis in producing itaconic acid. Microb Cell Fact 2012, 11:43.

29. Guevarra ED, Tabuchi T: Accumulation of itaconic, 2-hydroxyparaconic, itatartaric, and malic acids by strains of the genus Ustilago. Agric Biol Chem 1990, 54(9):2353-2358.

30. Kämper J, Kahmann R, Bölker M, Ma LJ, Brefort T, Saville BJ, Banuett F, Kronstad JW, Gold SE, Müller O, Perlin MH, Wösten HA, de-Vries R, RuizHerrera J, Reynaga-Peña CG, Snetselaar K, McCann M, Pérez-Martín J, Feldbrügge M, Basse CW, Steinberg G, Ibeas Jl, Holloman W, Guzman P, Farman M, Stajich JE, Sentandreu R, González-Prieto JM, Kennell JC, Molina $\mathrm{L}$, et al: Insights from the genome of the biotrophic fungal plant pathogen Ustilago maydis. Nature 2006, 444(7115):97-101

31. Schirawski J, Mannhaupt G, Münch K, Brefort T, Schipper K, Doehlemann G, Di-Stasio M, Rössel N, Mendoza-Mendoza A, Pester D, Müller O, Winterberg B, Meyer E, Ghareeb H, Wollenberg T, Münsterkötter M, Wong P, Walter M, Stukenbrock E, Güldener U, Kahmann R: Pathogenicity determinants in smut fungi revealed by genome comparison. Science 2010, 10:1546-1548.

32. Couturier M, Navarro D, Olivé C, Chevret D, Haon M, Favel A, LesageMeessen L, Henrissat B, Coutinho PM, Berrin JG: Post-genomic analyses of fungal lignocellulosic biomass degradation reveal the unexpected potential of the plant pathogen Ustilago maydis. BMC Genomics 2012, 13:57-71.

33. Mueller O, Kahmann R, Aguilar G, Trejo-Aguilar B, Wub A, de-Vries RP: The secretome of the maize pathogen Ustilago maydis. Fungal Genet Biol 2008, 45:63-70.

34. Mendgen $\mathrm{K}$, Hahn M: Plant infection and the establishment of fungal biotrophy. Trends Plant Sci 2002, 7:352-356.
35. Cano-Canchola C, Acevedo L, Ponce-Noyola P, Flores-Martínez I, Flores-Carre ón A, Leal-Morales CA: Induction of lytic enzymes by the interaction of Ustilago maydis with Zea mays tissues. Fungal Genet Biol 2000, 29:145-151.

36. Willis RB, Montgomery ME, Allen PR: Improved method for manual, colorimetric determination of total Kjeldahl nitrogen using salicylate. J Agric Food Chem 1996, 44:1804-1807.

37. Somogyi M: Notes on sugar determination. J Biol Chem 1952, 195:19-23.

38. Sambrook J, Russell DW: Molecular cloning: a laboratory manual. 3rd edition. New York: Cold Spring Harbor Laboratory Press; 2001.

39. Brachmann A, König J, Julius C, Feldbrügge M: A reverse genetic approach for generating gene replacement mutants in Ustilago maydis. Mol Genet Genomics 2004, 272:216-226.

40. Matthies $\mathrm{C}$, Erhard HP, Drake HL: Effects of $\mathrm{pH}$ on the comparative culturability of fungi and bacteria from acidic and less acidic forest soils. J Basic Microbiol 1997, 37(5):335-343.

41. Miyazaki K, Martin JC, Marinsek-Logar R, Flint HJ: Degradation and utilization of xylans by the rumen anaerobe Prevotella bryantii (formerly P. ruminicola subsp. brevis) B(1)4. Anaerobe 1997, 3(6):373-381.

42. Teplitsky A, Shulami S, Moryles S, Shoham Y, Shohama G: Crystallization and preliminary X-ray analysis of an intracellular xylanase from Bacillus stearothermophilus T-6. Acta Crystallogr D: Biol Crystallogr 2000, 56:181-184.

43. Fontes CM, Gilbert HJ, Hazlewood GP, Clarke JH, Prates JA, McKie VA, Nagy $T$, Fernandes $T H$, Ferreira LM: A novel Cellvibrio mixtus family 10 xylanase that is both intracellular and expressed under non-inducing conditions. Microbiology 2000, 146(8):1959-1967.

44. Sjostrom E: Wood Chemistry. Fundamentals and Applications. 2nd edition. San Diego: Academic press; 1993:292.

45. Petersen TN, Brunak S, von-Heijne G, Nielsen H: SignalP 4.0: discriminating signal peptides from transmembrane regions. Nat Methods 2011, 8:785-786.

46. English PD, Byrne JB, Albersheim P: Host-pathogen interactions. Plant Physiol 1971, 47:1-6.

47. Cantarel BL, Coutinho PM, Rancurel C, Bernard T, Lombard V, Henrissat B: The Carbohydrate-Active EnZymes database (CAZy): an expert resource for glycogenomics. Nucleic Acids Res 2009, 37:233-238.

48. Mewes HW, Amid C, Arnold R, Frishman D, Güldener U, Mannhaupt G, Münsterkötter M, Pagel P, Strack N, Stumpflen V, Warfsmann J, Ruepp A: MIPS: analysis and annotation of proteins from whole genomes. Nucleic Acids Res 2004, 32(Database issue):D41-44.

49. Eliasson A, Christensson C, Wahlbom CF, Hahn-Hägerdal B: Anaerobic xylose fermentation by recombinant Saccharomyces cerevisiae carrying XYL1, XYL2, and XKS1 in mineral medium chemostat cultures. Appl Environ Microbiol 2000, 66(8):3381-3386.

doi:10.1186/1472-6750-13-59

Cite this article as: Geiser et al: Identification of an endo-1,4-betaxylanase of Ustilago maydis. BMC Biotechnology 2013 13:59.

\section{Submit your next manuscript to BioMed Central and take full advantage of:}

- Convenient online submission

- Thorough peer review

- No space constraints or color figure charges

- Immediate publication on acceptance

- Inclusion in PubMed, CAS, Scopus and Google Scholar

- Research which is freely available for redistribution 